ORIGINAL ARTICLE

\title{
In vitro and in vivo antimalarial activity of the volatile oil of Cyperus articulatus (Cyperaceae)
}

Nazaré Carneiro da SILVA ${ }^{1}$, Suellen Ferreira GONÇALVES ${ }^{1}$, Luciana Silva de ARAÚJO', Aline Aparecida München KASPER², Amanda Luisa da FONSECA ${ }^{3}$, Adilson SARTORATTO 4 , Kelly Christina Ferreira CASTRO ${ }^{2}$, Tânia Mara Pires MORAES ${ }^{1}$, Leopoldo Clemente BARATTO ${ }^{5 *} \mathbb{D}$, Fernando de Pilla VAROTTI ${ }^{3}$, Lauro Euclides Soares BARATA² ${ }^{2}$, Waldiney Pires MORAES ${ }^{1}$

\footnotetext{
Universidade Federal do Oeste do Pará - UFOPA, Instituto de Saúde Coletiva - ISCO, Laboratório de Farmacologia, Av. Vera Paz, s/n, Bairro Salé, Santarém, Pará, Brasil 2 Universidade Federal do Oeste do Pará - UFOPA Instituto de Biodiversidade e Florestas - IBEF, Laboratório de Produtos Naturais Bioativos - P\&D-BIO, Av. Vera Paz, s/n, Bairro Salé, Santarém, Pará, Brasil

3 Universidade Federal de São João Del Rei - UFSJ, Núcleo de Pesquisa em Química Biológica - NQBio, Campus Centro-Oeste, Av. Sebastião Gonçalves Coelho 400, Bairro Chanadour, CEP 35501-296, Divinópolis, Minas Gerais, Brasil

${ }^{4}$ Universidade Estadual de Campinas - UNICAMP, Centro Pluridisciplinar de Pesquisas Químicas, Biológicas e Agrícolas - CPQBA, Av. Alexandre Cazelato 999 , Distrito de Betel, CEP 13148-218, Paulínia, São Paulo, Brasil

Universidade Federal do Rio de Janeiro - UFRJ, Centro de Ciências da Saúde, Faculdade de Farmácia, Laboratório de Farmacognosia Aplicada, Bloco A, $2^{\circ}$ andar, sala 30, Av. Brigadeiro Trompowski, s/n, Cidade Universitária, Ilha do Fundão, Rio de Janeiro, RJ, CEP 21.941-590, Brasil

* Corresponding author: leopoldo.ufrj@gmail.com; $\mathbb{D}$ https://orcid.org/0000-0002-7125-7431
}

\section{ABSTRACT}

Malaria is a disease of global tropical distribution, being endemic in more than 90 countries and responsible for about 212 million cases worldwide in 2016. To date, the strategies used to eradicate this disease have been ineffective, without specific preventive measures such as vaccines. Currently, the existing therapeutic arsenal is limited and has become ineffective against the expansion of artemisinin-resistant Plasmodium, demonstrating the need for studies that would allow the development of new compounds against this disease. In this context, we studied the volatile oil obtained from rhizomes of Cyperus articulatus (VOCA), a plant species commonly found in the Amazon region and popularly used as a therapeutic alternative for the treatment of malaria, in order to confirm its potential as an antimalarial agent by in vitro and in vivo assays. We cultured Plasmodium falciparum W2 (chloroquine-resistant) and 3D7 (chloroquine-sensitive) strains in erythrocytes and exposed them to VOCA at different concentrations in 96-well microplates. In vivo antimalarial activity was tested in BALB/c mice inoculated with approximately $10^{6}$ erythrocytes infected with Plasmodium berghei. VOCA showed a high antimalarial potential against the two $P$. falciparum strains, with $\mathrm{IC}_{50}=1.21 \mu \mathrm{g} \mathrm{mL}-1$ for W2 and $2.30 \mu \mathrm{g} \mathrm{mL}^{-1}$ for $3 \mathrm{D} 7$. VOCA also significantly reduced the parasitemia and anemia induced by $P$. berghei in mice. Our results confirmed the antimalarial potential of the volatile oil of Cyperus articulatus.

KEYWORDS: antiplasmodial, artemisinin resistance, chloroquine resistance, malaria, Plasmodium falciparum, Plasmodium berghei

\section{Atividade antimalárica in vitro e in vivo do óleo essencial de Cyperus articulatus (Cyperaceae)}

\section{RESUMO}

A malária é uma doença de distribuição tropical, sendo endêmica em mais de 90 países, responsável por cerca de 212 milhôes de casos reportados ao redor do mundo em 2016. As estratégias de erradicação dessa doença são ineficazes até o presente, sem medidas de prevenção específica, como vacinas. Atualmente, o arsenal terapêutico existente é limitado e vem se tornando ineficaz frente à expansão de plasmódios resistentes a artemisinina, evidenciando a necessidade de estudos que viabilizem o desenvolvimento de novos compostos contra a doença. Nesse contexto, estudamos o óleo essencial obtido de rizomas de Cyperus articulatus (VOCA), uma espécie vegetal comumente encontrada na região amazônica, utilizada popularmente como alternativa terapêutica para o tratamento de malária. Visamos confirmar o potencial antimalárico da planta através de testes in vitro e in vivo. Utilizamos cepas de Plasmodium falciparum W2 (cloroquina-resistente) e 3D7 (cloroquina-sensível) cultivadas em hemácias e expostas ao VOCA em microplacas de 96 poços. A atividade antimalárica in vivo foi testada em camundongos da linhagem $\mathrm{BALB} / \mathrm{c}$ infectados com aproximadamente $10^{6}$ eritrócitos parasitados por Plasmodium berghei. O VOCA apresentou alto potencial antimalárico $\left(\mathrm{IC}_{50}<10 \mu \mathrm{g} \mathrm{m} \mathrm{m}^{-1}\right)$ frente às duas cepas de $P$. falciparum testadas $\left(\mathrm{IC}_{50}=1,21 \mu \mathrm{g} \mathrm{ml}^{-1}\right.$ para W2 e 2,3 $\mu \mathrm{g} \mathrm{ml}^{-1}$ para 3D7). Além disso, houve redução significativa da parasitemia induzida por $P$. Berghei em camundongos tratados com EOAC, e também observamos diminuição da anemia, uma sintomatologia provocada pela infecçáo. Nossos resultados confirmam o potencial antimalárico do óleo essencial de Cyperus articulatus.

PALAVRAS-CHAVES: antiplasmódico, malária, Plasmodium falciparum, Plasmodium berghei, resistência à artemisinina, resistência à cloroquina

CITE AS: Silva, N.C. da; Gonçalves, S.F.; Araújo, L.S. de; Kasper, A.A.M.; Fonseca, A.L. da; Sartoratto, A.; Castro, K.C.F.; et at. 2019. In vitro and in vivo antimalarial activity of the volatile oil of Cyperus articulatus (Cyperaceae). Acta Amazonica 49: 334-342. 


\section{INTRODUCTION}

Malaria is an infectious and parasitic disease of global distribution related to prevailing seasonal factors in tropical and subtropical regions of sub-Saharan Africa, Southeast Asia and the Amazon Region (Reiners et al. 2010; Meneguetti et al. 2014). It remains a global health issue, endemic in more than 90 countries, with 212 million estimated cases worldwide in 2016 (WHO 2016).

According to the Panamerican Health Organization (PAHO 2018), after a decrease in the number of malaria cases from 2005 to 2014 in the region of the tropical Americas, an increase was observed between 2015 and 2017. In 2016, nine countries in the region (Colombia, Ecuador, El Salvador, Guyana, Haiti, Honduras, Nicaragua, Panama, and the Bolivarian Republic of Venezuela) reported an increase in malaria cases. In 2017, five countries reported an increase in cases: Brazil, Ecuador, Mexico, Nicaragua and Venezuela. Brazil reported 174,522 cases of malaria in 2017, while in 2016 the number of cases was 117,832 . The states that contributed with most cases were Amazonas, Pará and Acre (North region).

Malaria is caused by a protozoan of the genus Plasmodium Marchiafava \& Celli, 1885, which has approximately 150 species currently described, with only five species having been reported to be responsible for infecting humans: $P$. falciparum Welch, 1897; P. vivax Grassi \& Feletti, 1890; P. ovale Stephens, 1922; P. malariae Grassi \& Feletti, 1889 (França et al. 2008) and P. knowlesi Sinton and Mulligan 1933 (Rossati et al. 2016, Shearer et al. 2016). The transmission to humans occurs through the female bite of Anopheles Meigen 1818 mosquitoes infected with the protozoan. Most cases of severe malaria and death are caused by $P$. falciparum and its infection is responsible for the development of severe disease, affecting the central nervous system, and causing severe anemia, renal failure, pulmonary dysfunction, shock, disseminated intravascular coagulation, hypoglycemia, metabolic acidosis, and hepatic dysfunction (França et al. 2008; Gomes et al. 2011).

In the absence of an effective vaccine against malaria parasites (Tuju et al. 2017), appropriate treatment continues to be the basis of disease control (Landier et al. 2016). The therapeutic arsenal against malaria includes quinolines such as 4-aminoquinolines, 8-aminoquinolines and quinolinic alcohols including chloroquine, primaquine, quinine, mefloquine and lumefantrine (Brasil 2010), as well the endoperoxide sesquiterpene lactone artemisinin, the latter currently being the main antimalarial agent (WHO 2001). After the worldwide emergence of resistance of malaria parasites to chloroquine, the World Health Organization (WHO) recommended the use of artemisinin-based combination therapy (ACT) as the first-choice treatment for malaria (WHO 2001).

Although artemisinin remains effective in Brazil (Pinto et al. 2019), in the last decade artemisinin resistance has emerged and spread in Southeast Asia, impairing the therapeutic arsenal against malaria (Woodrow and White 2017). In this current scenario, the need for the identification of novel chemotherapeutic agents against resistant Plasmodium parasites is urgent.

Historically, natural products are the main sources for the development and production of antimalarial drugs, such as quinine, found in the bark of Cinchona spp. (Rubiaceae) and artemisinin isolated from Artemisia annua L. (Asteraceae), which represent the main existing antimalarial substances (Pohlit et al. 2013).

In the Amazon region, Cyperus articulatus L. (Cyperaceae), an aromatic plant popularly known as priprioca, stands out among the species used for therapeutic purposes. This native species occurs naturally in the North, Northeast and Southeast of Brazil (Flora do Brasil 2019). Cyperaceae contains small herbaceous plants (Goetghebeur 1998). The stalks of $C$. articulatus produce small tubers that, when cut, exude a fresh, woody and spicy scent, traditionally used in scented baths and in the manufacture of artisanal colonies in Northern Brazil, specially in Pará state (Nicoli et al. 2006). The species produces an intense, yellow volatile oil, which has economic value for perfumes and fragrance production in the cosmetic industry (Zoghbi et al. 2008).

Cyperaceae were cited by Bussmann and Glenn (2010) in their study on traditional treatments for malaria and fever in Northern Peru. Rhizomes (Rukunga et al. 2008) and leaves (Akendengue 1992) of C. articulatus are traditionally used to treat malaria. The congeneric $C$. longus L. has been identified as the plant named soád in traditional Iranian medicine books from the $11^{\text {th }}$ to $18^{\text {th }}$ centuries and indicated to treat malaria-like fever (Ghafari et al. 2013). Many other pharmacological properties have been described for $C$. articulatus such as anticonvulsant (Bum et al. 2001; Bum et al. 2003), sedative (Rakotonirina et al. 2001), antifungal (Duarte et al. 2005), antibacterial (Mongelli $e t$ al. 1994; Oladosu et al.2011; Azzaz et al.2014), and antioxidant (Azzaz et al. 2014) actions. The in vitro antiplasmodial potential of a methanol extract and chloroform fraction of $C$. articulatus has also been observed (Rukunga et al. 2008; Rukunga et al. 2009), yet there are no studies to date evaluating the antimalarial potential of the volatile oil of $C$. articulatus.

In this context, the objective of the present study was to analyze the chemical composition of the volatile oil of $C$. articulatus and to assess its antimalarial activity in in vitro and in vivo experimental models.

\section{MATERIAL AND METHODS}

\section{Plant material}

Cyperus articulatus was cultivated on a small scale basis in Tabocal (5443'00.10"W; 02³7'41.10”S), km 23 of the BR163 highway, in the municipality of Santarém, Pará, Brazil, in order to obtain raw material for our work. The rhizomes $(5 \mathrm{~kg}$ ) were collected in August 2014. The botanical material was identified by Dr. Antônio Elielson Sousa da Rocha, and a voucher specimen was deposited under registration MG- 
207174 in the herbarium of Museu Paraense Emilio Goeldi (MPEG) (Belém, Pará). After collection, the rhizomes were washed in running water, dried in an oven at $40^{\circ} \mathrm{C}$ for a period of three consecutive days and milled.

\section{Extraction of the volatile oil}

The milled plant material was extracted by steam distillation in a $150 \mathrm{~L}$ tank for $4 \mathrm{~h}$ in order to obtain the volatile oil of C. articulatus (VOCA). The VOCA yield was measured in $\mathrm{g} \mathrm{g}^{-1}$ fresh weight.

\section{Chromatographic analysis of the VOCA}

The chemical composition of the volatile oil was analyzed with a model HP-6890 Agilent gas chromatograph equipped with a mass selective Agilent HP-5975 detector using an HP-5MS capillary column $(30 \mathrm{~m} \times 0.25 \mathrm{~mm} \times 0.25 \mu \mathrm{m})$ under the following conditions: injector temperature $=220^{\circ} \mathrm{C}$, column $=60{ }^{\circ} \mathrm{C}$, heating rate $=3{ }^{\circ} \mathrm{C} \mathrm{min}{ }^{-1}$ up to $240{ }^{\circ} \mathrm{C}$, and detector $=250^{\circ} \mathrm{C}$. Helium was used as a carrier gas at a flow rate of $1 \mathrm{ml} \mathrm{min}{ }^{-1}$ with a selective mass detector operating at $70 \mathrm{eV}$, $m / z=30$ to $500 \mathrm{amu}$. The volatile oil was solubilized in ethyl acetate at a concentration of $20 \mathrm{mg} \mathrm{ml}^{-1}$. Quantitative data (\%) were obtained by peak areas according to the software of the chromatograph. Major extract compounds were identified by comparison with the electronic library of the equipment (NIST-11) and the literature (Adams 2007).

\section{In vitro assays}

Culture of intraerythrocytic stages of P. falciparum - The W2 (chloroquine-resistant) and 3D7 (chloroquine-sensitive) parasite strains (Laboratório da Malária da Fiocruz - Minas Gerais) were cultured in human erythrocytes in vitro under conditions previously established by Trager and Jensen (1976), with small modifications (Carvalho et al. 1991; AndradeNeto et al. 2004). The parasites were cultured in triplicate in Petri dishes with 5\% hematocrit using complete RPMI 1640 culture medium supplemented with $25 \mathrm{mM}$ Hepes, $21 \mathrm{mM}$ sodium bicarbonate, $300 \mu \mathrm{M}$ hypoxanthine, $11 \mathrm{mM}$ glucose, $40 \mu \mathrm{g} \mathrm{ml}^{-1}$ gentamicin and $10 \%$ inactivated human plasma. All reagents were purchased from Sigma-Aldrich (São Paulo, Brazil). The dishes were maintained at $37{ }^{\circ} \mathrm{C}$ in desiccators in which the adequate concentration of $\mathrm{O}_{2}$ was obtained by the combustion of a candle, and the medium was exchanged daily. Parasitemia was monitored daily in Giemsa-stained smears under an optical microscope $(1000 \mathrm{x})$.

Synchronization of P. falciparum culture - The parasite cultures were synchronized by the sorbitol method (Lambros and Vanderberg 1979) and the culture with a predominance of young forms (rings), obtained soon after the synchronization, was used in the antimalarial assays.

Schizonticidal tests against P. falciparum using the traditional microtest - Plasmodium falciparum (W2 and 3 D7) cultures synchronized with $2 \%$ parasitemia in the ringshaped stage and 2\% hematocrit were distributed in 96-well microplates. After approximately $1 \mathrm{~h}$ of incubation, $25 \mu \mathrm{l}$ of RPMI medium were added to each well containing different concentrations $\left(1.56,3.12,6.25,12.5,25\right.$ and $\left.50 \mu \mathrm{g} \mathrm{ml}^{-1}\right)$ of the VOCA; chloroquine was used as positive control. After 24 and $48 \mathrm{~h}$ incubation at $37^{\circ} \mathrm{C}$ in a desiccator, the culture medium was changed in each well. A blood smear of all Giemsa-stained samples was prepared after $72 \mathrm{~h}$ and analyzed by light microscopy to determine parasitemia. Results were expressed as $\mathrm{IC}_{50}$ (Carvalho et al. 1991). All experiments were performed in triplicate with three plates.

Human lung fibroblast culture - The WI-26 VA4 cell line (human lung fibroblast, ATCC\#: CCL-75) was kindly supplied by Dr. Luciana Maria Silva (Fundação Ezequiel Dias, Belo Horizonte-MG, Brazil). Cells were thawed at $37^{\circ} \mathrm{C}$ and their contents transferred to a $50-\mathrm{ml}$ tube with $20 \mathrm{ml}$ of incomplete RPMI medium. The cells were then centrifuged at $320 \mathrm{x} g$ for 5 min, the supernatant was discarded and the pellet resuspended in complete RPMI medium supplemented with 5\% fetal bovine serum and $40 \mathrm{mg} \mathrm{l}^{-1}$ gentamicin. Cells were then transferred to three $200-\mathrm{ml}$ culture bottles and placed in a $\mathrm{CO}_{2}$ incubator at $37^{\circ} \mathrm{C}$. The medium was changed every 2 days. After $80 \%$ confluence, the culture was used in the cytotoxicity assays.

Cytotoxicity assays - WI 26VA-4 cells in culture were trypsinized with $1 \mathrm{ml}$ of trypsin, incubated at $37{ }^{\circ} \mathrm{C}$ for 5 min, resuspended in $10 \mathrm{ml}$ of complete RPMI medium and centrifuged at $320 \mathrm{~g}$ for $5 \mathrm{~min}$. The supernatant was discarded and the pellet resuspended in complete medium. Cells were distributed into 96 -well microplates $\left(4 \times 10^{5}\right.$ cells $/ 100 \mu \mathrm{l}$ per well) and placed in a $\mathrm{CO}_{2}$ incubator at $37^{\circ} \mathrm{C}$ for $24 \mathrm{~h}$ for cell adhesion to the plate. In the next step, $100 \mu$ of complete medium containing different concentrations $\left(0.1\right.$ to $100 \mu \mathrm{g} \mathrm{ml}^{-}$ $\left.{ }^{1}\right)$ of the test samples were added. After $24 \mathrm{~h}$ incubation, $20 \mu \mathrm{l}$ of a solution of 3-(4,5-dimethylthiazol-2-yl)-2,5-diphenyltetrazol (MTT) bromide ( $5 \mathrm{mg} \mathrm{ml}^{-1}$ in phenol-free RPMI) was added to each well. After $3 \mathrm{~h}$ incubation, the supernatant was removed and the formed dye diluted with $50 \mu \mathrm{l}$ DMSO. All experiments were performed in triplicate with three plates. The microplates were read in a spectrophotometer at $570 \mathrm{~nm}$ and the results were expressed as $\mathrm{IC}_{50}$ (Moreira et al. 2015). The selectivity index (SI) was obtained by the ratio between the $\mathrm{IC}_{50}$ value of WI 26VA-4 and the $\mathrm{IC}_{50}$ value of $P$. falciparum.

\section{In vivo assays}

Animals - The experiment was performed with healthy Balb/c mice aged 30 to 60 days, from the Animal Facility of Universidade Federal do Oeste do Pará (Campus Oriximiná). The animals were kept at a controlled temperature of 22 $\pm 2{ }^{\circ} \mathrm{C}$, on a dark-light cycle of $12 \mathrm{~h}$ with balanced feed (Labina ${ }^{\circledR}$ ) and water ad libitum. The management and care of the animals followed the ethical principles of animal experimentation, according to the criteria established by the Animal Use Committee of Universidade Federal do Oeste do Pará (UFOPA), under approved protocol \# 02001/2015. 
Evaluation of acute toxicity - Acute oral toxicity was determined according to the OECD-423/2001 guidelines "Acute Toxic Class Method" (OECD 2001), which determine fixed doses of 5, 50, 300 and $2000 \mathrm{mg} \mathrm{kg}^{-1}$, and the number of three animals per group. The initial dose was $5 \mathrm{mg} \mathrm{kg}^{-1}$ and the other doses were tested depending on the mortality observed during the first $24 \mathrm{~h}$ of exposure. Each dose was tested twice and the toxicological category was estimated according to the especifications. VOCA was solubilized in $4 \%$ Tween 80 ; the animals in the control group received only saline solution with $4 \%$ Tween 80 . Doses were administered orally. The animals were assessed for general activity, vocal fremitus, irritability, reflex, contortion, ataxia, tremors, convulsions, hypnosis, anesthesia, lacrimation, piloerection, hypothermia, respiration, cyanosis, hyperemia, and death $30 \mathrm{~min}$ and 1, 2, 3 and $4 \mathrm{~h}$ after administration of VOCA, and thereafter, daily up to the $14^{\text {th }}$ day. All animals were weighed before and on the $7^{\text {th }}$ and $14^{\text {th }}$ day after VOCA administration.

Induction of the experimental model in vivo - The assay was performed by the adapted test described by Peters (1985), in which the malaria model was induced by intraperitoneal inoculation of approximately $10^{6}$ erythrocytes infected with the Plasmodium berghei (PbA) ANKA strain in female Balb/c mice.

Determination of parasite density - Parasitemia was determined on the $4^{\text {th }}, 7^{\text {th }}$ and $11^{\text {th }}$ day after inoculation using a blood smear stained with Giemsa and reading of 1,000 erythrocytes under an optical microscope $(1000 \mathrm{x})$. The percentages of parasitemia and suppression were determined using the modified model proposed by Girma et al. (2015) according to the equations below:

$\%$ parasitemia $=\underline{\text { number of infected erythrocytes }} \times 100$ total number of erythrocytes

$\%$ suppression $=$ parasitemia of untreated animals - parasitemia of treated animals $\times 100$ parasitemia in untreated animals

Experimental design - The animals ( $\mathrm{n}=36$; six animals per group) were randomly divided into six groups: Group $1=$ vehicle (PBS) control (uninfected animals); Group 2 = negative control (P. berghei-infected and untreated animals); Group $3=$ positive control (P. berghei-infected animals orally treated with a daily dose of $100 \mathrm{mg} \mathrm{kg}^{-1}$ artemisinin); Groups 4, 5 and $6=$ P. berghei-infected animals orally treated with VOCA at daily doses of 200, 100 and $10 \mathrm{mg} \mathrm{kg}^{-1}$, respectively, diluted in $4 \%$ Tween 80 using PBS as vehicle. The selected doses corresponded to $1 / 200,1 / 20$ and $1 / 10$ of the maximum dose tested in the acute toxicity test. The treatments were started on the $4^{\text {th }}$ day after inoculation of $P$. berghei and were continued daily until the $11^{\text {th }}$ day, when the animals were sacrificed for the collection of biological material by cardiac puncture.

Hematological parameters - At the end of treatment, a complete blood cell count was performed, i.e., total erythrocyte count, hemoglobin quantification and hematocrit determination. The hemogram was performed on a Mindray Hematology Analyzer, BC2800 veterinary model.

\section{Statistical analyses}

$\mathrm{IC}_{50}$ values from in vitro tests were calculated using Origin Lab Corporation software (Northampton, MA, USA). Hematological parameters were compared among the in vivo test groups by ANOVA followed by the Tukey test using Graph Pad Software Prism 7.0 (San Diego, CA, USA), with the level of significance set at ${ }^{*} p \leq 0.05 ;{ }^{* *} p \leq 0.01 ;{ }^{* * *} p \leq 0.001$.

\section{RESULTS}

\section{Chromatographic analysis of the VOCA}

The VOCA yield was $0.6 \%\left(\mathrm{~g} \mathrm{~g}^{-1}\right)$. Chemical characterization by GC-MS led to the identification of 37 compounds (Table 1), $9.96 \%$ of which were non-oxygenated monoterpenes, 5.03\% oxygenated monoterpenes, $23.3 \%$ non-oxygenated sesquiterpenes, and $41.5 \%$ oxygenated sesquiterpenes. Major compounds were mustakone $(9.9 \%)$, cyclocolorenone $(7.4 \%)$, $\alpha$-copaene (4.4), $\alpha$-selinene (4.4) and cis-thujopsenal (4.0\%), while $20.6 \%$ of the compounds could not be identified by molecular weigth comparison.

\section{In vitro assays}

VOCA was non-cytotoxic for human lung fibroblasts by cell viability assay with $\mathrm{MTT}\left(\mathrm{IC}_{50}>100 \mu \mathrm{g} \mathrm{ml}^{-1}\right)$. The $\mathrm{IC}_{50}$ values of $P$. falciparum $\mathrm{W} 2$ and $3 \mathrm{D} 7$ strains treated with VOCA were $1.21 \mu \mathrm{g} \mathrm{ml}^{-1}$ and $2.30 \mu \mathrm{g} \mathrm{ml}^{-1}$, respectively. Chloroquine showed $\mathrm{IC}_{50}=0.46 \mu \mathrm{g} \mathrm{ml}^{-1}$ and $0.21 \mu \mathrm{g} \mathrm{ml}^{-1}$ for W2 and 3D7 strains, respectively. The VOCA SI was greater than 80 for the W2 strain and greater than 40 for the 3 D7 strain (Table 2).

\section{In vivo assays}

In the acute toxicity test, after the first dose $\left(5.0 \mathrm{mg} \mathrm{kg}^{-1}\right)$, no mortality nor protocolar affection was observed for the three exposed animals in the group in the first $4 \mathrm{~h}$, nor over the next 14 days. The test was repeated with the same number of animals and VOCA concentration, confirming the previous result. Thus, the concentrations of 50, 300 and $2000 \mathrm{mg}$ $\mathrm{kg}^{-1}$ were administered following the same experimental procedures and VOCA was found to satisfy all the parameters prescribed by the OECD 423 guideline (OECD 2001) for a safe compound. The acute toxic dose of VOCA is therefore greater than 2,000 $\mathrm{mg} \mathrm{kg}^{-1}$ in Balb/c mice, thus being classified as a category 5 compound in the Globally Harmonized Classification System (GHS). No clinical change or mortality was observed at any dose. No significant differences were observed in body mass (Table 3). No morbidity or any visible signs of intoxication were recorded, and all the animals were active and seemed healthy at the end of the observation period. 
Treatment with VOCA at all three concentrations tested significantly reduced the parasitemia induced by $P$. berghei (Figure 1). On the $11^{\text {th }}$ day after inoculation, the parasitemia suppression values were $75.2 \%, 74.8 \%$ and $48.9 \%$ for groups 4, 5 and 6, respectively. Treatment with $100 \mathrm{mg} \mathrm{kg}^{-1}$ artemisinin (Group 3) promoted $100 \%$ suppression of the parasites.

There was a significant increase of $144.9 \%$ and $120.1 \%$ in the number of erythrocytes, $94.2 \%$ and $90.6 \%$ in

Table 1. Chemical composition of the volatile oil of Cyperus articulatus from Santarém (Pará State, Brazil) by GC-MS. Kl = Kovatz index [values are from Adams (2007) and were used as supporting reference for the elution order]. \% rel = relative percentage.

\begin{tabular}{|c|c|c|c|}
\hline$t_{R}(\min )$ & $\mathrm{KI}$ & Compound & $\%$ rel \\
\hline 5.77 & 933 & $\alpha$-pinene & 5.37 \\
\hline 6.29 & 953 & thuja-2,4(10)-diene & 0.42 \\
\hline 6.93 & 977 & $\beta$-pinene & 3.07 \\
\hline 8.39 & 1024 & p-cymene & 0.50 \\
\hline 8.53 & 1028 & limonene & 0.60 \\
\hline 12.13 & 1126 & $\alpha$-campholenal & 0.31 \\
\hline 12.68 & 1140 & trans-pinocarveol & 1.44 \\
\hline 13.60 & 1162 & pinocarvone & 0.52 \\
\hline 13.83 & 1168 & p-mentha-1,5-dien-8-ol & 0.60 \\
\hline 15.01 & 1197 & myrtenal & 2.16 \\
\hline 22.54 & 1376 & $\alpha$-copaene & 4.42 \\
\hline 23.48 & 1398 & cyperene & 1.70 \\
\hline 23.74 & 1405 & cis-thujupsadiene & 1.18 \\
\hline 25.08 & 1438 & $\alpha$-guaiene & 0.72 \\
\hline 25.89 & 1458 & rotundene & 0.88 \\
\hline 26.45 & 1472 & $\beta$-selinene & 0.31 \\
\hline 26.52 & 1474 & 4,5,9,10-dehydro-isolongifolene & 0.54 \\
\hline 26.63 & 1477 & $\alpha$-amorphene & 1.04 \\
\hline 27.04 & 1487 & $\alpha$-selinene & 4.38 \\
\hline 27.37 & 1495 & eudesma-4(14),7(11)-diene & 0.96 \\
\hline 27.81 & 1506 & $\alpha$-bulnesene & 2.16 \\
\hline 29.26 & 1543 & $\alpha$-calacorene & 1.16 \\
\hline 30.50 & 1575 & cedrene epoxide & 2.53 \\
\hline 30.73 & 1581 & calamenene & 1.32 \\
\hline 30.82 & 1584 & caryophylene oxide & 3.73 \\
\hline 31.00 & 1588 & spathulenol & 2.82 \\
\hline 31.19 & 1593 & $\beta$-copaen-4- $\alpha$-ol & 1.37 \\
\hline 31.79 & 1609 & humulene epoxide & 1.27 \\
\hline 32.84 & 1638 & eudesma-3,11-dien-5-ol & 1.56 \\
\hline 33.51 & 1656 & pogostol & 2.54 \\
\hline 34.44 & 1681 & mustakone & 9.91 \\
\hline 34.56 & 1684 & cyperol & 2.55 \\
\hline 34.96 & 1695 & cyperotundone & 2.79 \\
\hline 35.51 & 1711 & cis-thujopsenal & 4.05 \\
\hline 35.81 & 1719 & 14-hidroxi- $\alpha$-humulene & 0.55 \\
\hline 36.98 & 1753 & cyclocolorenone & 7.42 \\
\hline 37.63 & 1771 & $\alpha$-cyperone & 0.59 \\
\hline Total identified (\%) & & & 79.44 \\
\hline
\end{tabular}

the amount of hemoglobin, and $105.5 \%$ and $82.1 \%$ in the percentage of hematocrit for Groups 4 and 5, respectively, in relation to Group 2. Results for Group 6 were not statistically relevant. Treatment with 100 $\mathrm{mg} \mathrm{kg}{ }^{-1}$ artemisinin (Group 3) promoted a significant increase of $205.5 \%, 121.0 \%$ and $129.7 \%$ in the number of erythrocytes, hemoglobin quantity and hematocrit percentage, respectively (Table 4).

Table 2. In vitro antiplasmodial activity, cytotoxicity (human lung fibroblast, Wi 26VA-4) and selectivity index (SI) of the volatile oil of Cyperus articulatus rhizomes (VOCA) against Plasmodium falciparum strains W2 and 3D7, and using chloroquine as control. Values are the mean \pm SE.

\begin{tabular}{|c|c|c|c|c|c|}
\hline \multirow[b]{2}{*}{ Treatments } & \multicolumn{3}{|c|}{$\mathrm{IC}_{50}\left(\mu \mathrm{g} \mathrm{ml}^{-1}\right)$} & \multicolumn{2}{|c|}{ SI } \\
\hline & W2 & $3 \mathrm{D} 7$ & Wi 26VA-4 & 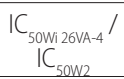 & $\begin{array}{c}\mathrm{IC}_{50 \mathrm{~W} i 26 \mathrm{~V}-4} \mathrm{I} \\
\mid \mathrm{C}_{50307}\end{array}$ \\
\hline VOCA & $1.21 \pm 0.05$ & $2.30 \pm 0.09$ & $>100$ & $>80$ & $>40$ \\
\hline Chloroquine & $0.46 \pm 0.08$ & $0.21 \pm 0.01$ & $>100$ & $>100$ & $>200$ \\
\hline
\end{tabular}

Table 3. Body weight (g) of Balb/c mice ( $n=6$ per group) treated orally with increasing doses of volatile oil of Cyperus articulatus rhizomes (VOCA) (5, 50, 300 and 2,000 $\mathrm{mg} \mathrm{kg}^{-1}$ ) during 14 days for acute toxicity evaluation. Values are the mean \pm SEM

\begin{tabular}{lccccc}
\hline & \multirow{2}{*}{ Control } & \multicolumn{4}{c}{ VOCA concentration } \\
\cline { 3 - 6 } & & 5 & 50 & 300 & 2,000 \\
\hline Day 0 & $24.02 \pm 1.28$ & $24.08 \pm 2.56$ & $24.18 \pm 3.77$ & $25.03 \pm 0.67$ & $24.85 \pm 0.57$ \\
Day 7 & $25.28 \pm 2.51$ & $26.02 \pm 0.59$ & $26.08 \pm 1.27$ & $27.20 \pm 1.64$ & $26.89 \pm 1.03$ \\
Day 14 & $25.99 \pm 2.96$ & $26.36 \pm 1.75$ & $28.19 \pm 0.89$ & $28.71 \pm 1.60$ & $29.40 \pm 1.31$ \\
\hline
\end{tabular}

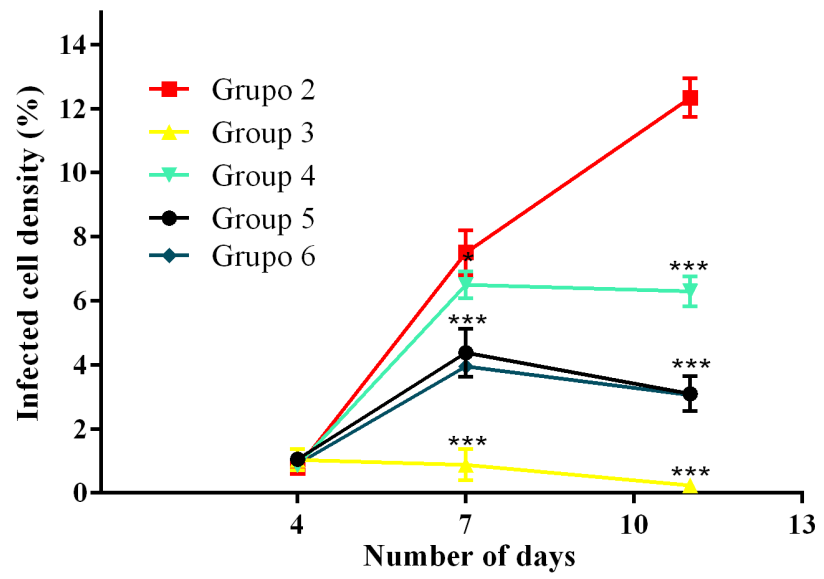

Figure 1. Parasitemia evolution in Plasmodium berghei-infected Balb/c mice through the percentage of infected cells. Each point represents the average \pm standard error of mean (SEM) ( $n=6$ per group). Group 2 (untreated malaria); Group 3 (artemisinin $100 \mathrm{mg} \mathrm{kg}^{-1}$ day); Groups 4, 5 and 6 (VOCA 200, 100 and $10 \mathrm{mg} \mathrm{kg}^{-1}$ day). Asterisks indicate significant differences relative to Group 2. ${ }^{*} p<0.05$; ${ }^{* * *}$ $p<0.001$. VOCA $=$ volatile oil obtained from rhizomes of Cyperus articulatus. This figure is in color in the electronic version. 
Table 4. Hematological analysis (mean $\pm S E M$ ) of $P$. berghei-infected Balb/c mice ( $n=6$ per group) after 11 days of treatment with volatile oil of Cyperus articulatus (VOCA) and artemisinin.

\begin{tabular}{llll}
\hline Treatment & Erythrocytes $\left(10^{6} \mu^{-1}\right)$ & Hemoglobin $\left(\mathrm{g} \mathrm{dl}^{-1}\right)$ & Hematocrit (\%) \\
\hline Group 1 & $9.48 \pm 0.49$ & $14.46 \pm 1.21$ & $49.50 \pm 1.16$ \\
Group 2 & $3.28 \pm 0.61^{* * *}$ & $6.16 \pm 0.99^{* * *}$ & $20.92 \pm 3.53^{* * *}$ \\
Group 3 & $10.04 \pm 2.03^{* * *}$ & $13.62 \pm 2.50^{* * *}$ & $48.06 \pm 8.3^{* * *}$ \\
Group 4 & $8.04 \pm 3.41^{* *}$ & $14.77 \pm 0.49^{* *}$ & $43.03 \pm 13.5^{* *}$ \\
Group 5 & $7.23 \pm 2.60^{* *}$ & $11.74 \pm 2.59^{* *}$ & $38.10 \pm 11.44^{*}$ \\
Group 6 & $3.60 \pm 0.35$ & $6.94 \pm 0.85$ & $25.34 \pm 3.07$ \\
\hline
\end{tabular}

Group1: control; Group 2: untreated malaria; Group 3: artemisinin $100 \mathrm{mg} \mathrm{kg}^{-1}$ : Groups 4, 5 and 6:VOCA 200, 100 and $10 \mathrm{mg} \mathrm{kg}^{-1}$. Asterisks for Group 2 indicate significant differences in relation to Group 1. Asterisks for Groups 3, 4 and 5 indicate significant differences relative to Group 2. ${ }^{*} p<0.05 ; * * p<0.01 ; * * * p<0.001$.

\section{DISCUSSION}

Couchman et al. (1964) identified myrtenal, myrtenol and articulone in the volatile oil of $C$. articulatus from Nigeria. Nyasse et al. (1988) reported the main chemical compounds found in the hexane extract of the $C$. articulatus rhizomes from Cameroon, including mandassidione, mustakone and isopatchoul-4(5)en-3-one, all sesquiterpene diketones. These same compounds were also detected by Zoghbi et al. (2006) in rhizome volatile oil from Pará state (Brazil), with a 14.5\% content of mustakone, as well as caryophyllene oxide (10.1\%) and $\alpha$-pinene (6.5\%). Zoghbi et al.(2008) compared the chemical composition of the volatile oil of the rhizomes of $C$. articulatus var. nodosus collected in different localities in Pará. The main compounds were $\alpha$-pinene (3.6-25.3\%), $\beta$-pinene (2.2-12.5\%), trans-pinocarolol (2.1-5.4\%), myrtenal + myrtenol (2.2-5.5\%), $\alpha$-copaene $(1.4-2.7 \%)$, cyperene (0.6-1.5\%), $\beta$-selinene (0.9-2.5\%), lithol (0.8-5.0\%), caryophyllene oxide (3.0-8.2\%), mustakone (3.3-9.8\%), cyperotundone $(2.5-4.0 \%)$ and $\alpha$-cyperone $(3.3-8.9 \%)$.

Mustakone was the major compound $(9.91 \%)$ in our sample of $C$. articulatus rhizomes from Santarém, a locality that was not sampled by Zoghbi et al. (2008). We report other substances for the first time for VOCA (cyclocolorenone and cis-thujopsenal). Quali-quantitative differences in the composition of volatile oils may be due to the influence of several factors such as temperature, luminosity, seasonality, developmental stage, harvesting time, water availability, UV radiation, altitude, air pollution, nutrients, pathogens etc. (Adams 2007; Olawore et al. 2006; Hassanein et al. 2014).

Our results for the cytotoxicity tests and the acute lethal toxicity of VOCA were similar to those reported by Metuge et $\mathrm{al}$. (2014) for C. articulatus from Cameroon, who found an $\mathrm{IC}_{50}=$ $93.7 \mu \mathrm{g} \mathrm{ml}^{-1}$ using monkey kidney cells to assess cytotoxicity and also determined the toxic dose in mice to be greater than 2,000 $\mathrm{mg} \mathrm{kg}{ }^{-1}$ under acute exposure conditions. Rukunga et al. (2008) described the antiplasmodial activity of two sesquiterpenes isolated from the chloroform extract of the rhizomes of $C$. articulatus from Kenya: corymbolone $\left(\mathrm{IC}_{50}=1.07\right.$ and 1.92 $\mu \mathrm{g} \mathrm{ml}^{-1}$ ) and mustakone $\left(\mathrm{IC}_{50}=0.14\right.$ and $0.25 \mu \mathrm{g} \mathrm{ml}^{-1}$ ) against NF 54 and ENT 36 cell strains, respectively. Mustakone was about 10 times more efficient than corymbolone.

Sesquiterpenes present in tubers of $C$. rotundus from Thailand, among them patchoulenone, $\alpha$-caryophyllene oxide, 10,12-peroxycalamenene and 4,7-dimethyl-1-tetralone, showed antimalarial activity (Thebtaranonth et al. 1995). The ethyl acetate extract of tubers of $C$. rotundus from eastern India showed antimalarial activity with an $\mathrm{IC}_{50}$ up to $10 \mu \mathrm{g} \mathrm{ml}^{-1}$, being effective against the 3D7 and INDO (choloroquineresistant) strains of $P$. falciparum (Kaushik et al. 2013).

In the development of new antimalarial drugs, substances with a high selectivity index (SI) are sought, indicating their specificity for infected erythrocytes (Basore et al. 2015). A drug with antimalarial potential should have a SI greater than 10 (Katsuno et al. 2015). According to this parameter, VOCA exhibited an excellent SI in our tests, with a value greater than 80 for the P. falciparum W2 strain and 40 for the P. falciparum 3D7 strain.

Interestingly, we observed that some of the major compounds of VOCA (mustakone and cyclocolorenone), as well some minor compounds (cyperotundone and $\alpha$-cyperone), contained an $\alpha, \beta$-unsaturated carbonyl moiety. The antimalarial potential of these compounds may be related to the tendency of the nucleic acids of Plasmodium to react with the $\alpha, \beta$ unsaturated carbonyl moiety (Weenen et al. 1990).

In addition to the in vitro efficacy, our in vivo results also showed VOCA to be active in reducing malarial parasitemia levels, as $48.9 \%$ suppression at $10 \mathrm{mg} \mathrm{kg}^{-1}$ and $>74 \%$ at 100 and $200 \mathrm{mg} \mathrm{kg}^{-1}$ are above the threshold of $40 \%$ parasite suppression in vivo proposed for a compound to be considered active (Coutinho et al. 2013; Rezende et al. 2013). Samy and Kadarkari (2011) evaluated the antimalarial potential of extracts from $C$. rotundus leaves from western India, alone or in combination with chloroquine, against $P$. berghei tolerant to chloroquine (NK65 strain). Mice treated with a dose of $500 \mathrm{mg} \mathrm{kg}^{-1}$ of crude extract (CE), methanolic extract $(\mathrm{ME})$ and the cyclohexane $(\mathrm{CH})$ and methylene chloride (MC) fractions showed $84,87,85$ and $80 \%$ parasitemia inhibition, respectively. The survival rate was $58,55,59$ and $50 \%$ for the animals treated with $\mathrm{CH}, \mathrm{MC}, \mathrm{CE}$ and $\mathrm{ME}$, respectively. When the fractions were used in combination with chloroquine, the percentages of parasitemia inhibition were $87,83,87$ and $90 \%$, and the survival rate was 60,58 , 61 and $63 \%$, respectively. Our results thus reinforce the body of evidence for the antimalarial potential of Cyperus species.

Anemia represents the severe phase of malaria and can be lethal (Asangha et al. 2017). The significantly higher values of hematological parameters (erythrocytes, hematocrit and hemoglobin) in the groups tested with VOCA relative to the negative control in our study may be strongly associated 
with a decrease in hemolysis, since parasitemia was reduced, reversing the frequent anemia occurring in malaria. Our results corroborate those obtained by Ballal et al. (2011) for gum arabic. The reduction of parasitemia in more than $74 \%$ in mice treated with both higher VOCA concentrations also points to the inhibition of the natural progression of the infection through contention of excessive hemolysis and parasite release.

Artemisinin is one of the standard drugs used as positive control in experimental models using Balb/c mice (Agarwal et al. 2015; Sousa et al. 2017; Recuenco et al. 2017). The significant decrease in parasitemia and increase in the number of erythrocytes, hematocrit and hemoglobin levels in Group 3 relative to the negative control is evidence for the efficacy of the experimental model designed for our study, and showed that higher concentrations of VOCA can have a similar effect on hematological parameters as artemisinin. It is important to take into account that VOCA is a complex mixture of several volatile compounds that can act synergistically, while artemisinin is a pure isolated substance.

\section{CONCLUSIONS}

The volatile oil obtained from the rhizomes of Cyperus articulatus (VOCA) cultivated in Santarém (Pará state, Brazil) contained mustakone as major identified compound, and exhibited a low $\mathrm{IC}_{50}$ against two strains of Plasmodium falciparum (W2 and 3D7). We also demonstrated a significant effect of the volatile oil on the suppression of parasitemia in P. berghei-infected Balb/c mice, as well as significantly lower anemia in animals treated with 100 and $200 \mathrm{mg} \mathrm{kg}^{-1}$ VOCA relative to untreated infected animals, disrupting erythrocytic schizogony. VOCA also had low cytotoxicity against the WI26 VA4 human strain and had acute toxicity in vivo at doses of more than $2,000 \mathrm{mg} \mathrm{kg}^{-1}$. In comparison with the positive control artemisinin, VOCA exhibited promising results. Our results show the therapeutic potential of Amazonian $C$. articulatus for the treatment of malaria, an endemic disease in the northern region of Brazil.

\section{ACKNOWLEDGMENTS}

This work was funded by Fundação Amazônia de Amparo a Estudos e Pesquisas do Pará - FAPESPA.

\section{REFERENCES}

Adams, R.P. 2007. Identification of essential oil components by gas chromatography/mass spectroscopy. $4^{\text {th }}$ ed. Allured Publishing Corporation, Illinois, 798p.

Agarwal, D.; Sharma, M.; Dixit, S.K.; Dutta, R.K.; Singh, A.K.; Gupta, R.D.; Awasthi, S.K. 2015. In vitro synergistic effect of fluoroquinolone analogues in combination with artemisinin against Plasmodium falciparum; their antiplasmodial action in rodent malaria model. Malaria Journal, 14: 48.
Akendengue, B. 1992. Medicinal plants used by the Fang traditional healers in Equatorial Guinea. Journal of Ethnopharmacology, 37: 165-173.

Andrade-Neto, V.F.; Brandão, M.G.; Oliveira, F.Q.; Casali, V.W.; Njaine, B.; Zalis, M. G; et al. 2004. Antimalarial activity of Bidens pilosa L. (Asteraceae) ethanol extracts from wild plants collected in various localities or plants cultivated in humus soil. Phytotherapy Research, 18: 634-639.

Ariey, F.; Witkowski, B.; Amaratunga, C.; Beghain, J.; Langlois, A.C.; Khim, N; et al. 2014. A molecular marker of artemisinin-resistant Plasmodium falciparum malaria. Nature, 505: 50-55.

Asangha, E.E.; Igile, G.O.; Iwara, I.A.; Ebong, P.E.; Eseyin, O.A. 2017. Hematological indices of Plasmodium berghei infected mice treated with ethanol extract and fractions of Nauclea latifolia roots. International Journal of Current Microbiology and Applied Sciences, 6: 2546-2556.

Azzaz, N.A.; El-khateeb, A.Y.; Farag, A.A. 2014. Chemical composition and biological activity of the essential oil of Cyperus articulatus. International Journal of Academic Research, 6: 265-269.

Ballal, A.; Bobbala, D.; Qadri, S.M.; Föller, M.; Kempe, D.; Nasir, O.; Saeed, A.; Lang, F. 2011. Anti-malarial effect of gum arabic. Malaria Journal, 10: 139.

Basore, K.; Cheng, Y.; Kushwaha, A.K.; Nguyen, S.T.; Desai, S.A. 2015. How do antimalarial drugs reach their intracellular targets? Frontiers in Pharmacology, 6: 1-7.

Brasil 2010. Ministério da Saúde. Secretaria de Vigilância em Saúde. Departamento de Vigilância Epidemiológica. Guia prático de tratamento da malária no Brasil. Série A. Normas e Manuais Técnicos. Brasília: Ministério da Saúde. 36p. (http:// bvsms.saude.gov.br/bvs/publicacoes/guia_pratico_malaria.pdf). Accessed on 09 Nov 2018.

Bum, E.N.; Rakotonirina, A.; Rakotonirina, S.V.; Herrling, P. 2003. Effects of Cyperus articulatus compared to effects of anticonvulsant compounds on the cortical wedge. Journal of Ethnopharmacology, 87: 27-34.

Bum, E.N.; Schmutz, M.; Meyer, C.; Rakotonirina, A.; Bopelet, M.; Portet, C.; et al. 2001. Anticonvulsant properties of the methanolic extract of Cyperus articulatus (Cyperaceae). Journal of Ethnopharmacology, 76: 145-150.

Bussmann, R.W.; Glenn, A. 2010. Cooling the heat-Traditional remedies for malaria and fever in Northern Peru. Ethnobotany Research and Applications, 8: 125-134.

Carvalho, L.H.; Brandao, M.G.; Santos-Filho, D.; Lopes, J.L.; Krettli, A.U. 1991. Antimalarial activity of crude extracts from Brazilian plants studied in vivo in Plasmodium berghei-infected mice and in vitro against Plasmodium falciparum in culture. Brazilian Journal of Medical and Biological Research, 24: 11131123.

Couchman, F.M.; Pinder, A.R.; Bromham, N.H. 1964. Studies on the essential oil of Cyperus articulatus L. Tetrahedron, 20: 2037-2045.

Coutinho, J.P.; Aguiar, A.C.C.; Santos, P.A.D.; Lima, J.C.; Rocha, M.G.L.; Zani, C.L; et al. 2013. Aspidosperma (Apocynaceae) plant cytotoxicity and activity towards malaria parasites. Part I: Aspidosperma nitidum (Benth) used as a remedy to treat fever 
and malaria in the Amazon. Memórias do Instituto Oswaldo Cruz, 108: 974-982.

Duarte, M.C.T.; Figueira, G.M.; Sartoratto, A.; Rehder, V.L.G.; Delarmelina, C. 2005. Anti-Candida activity of Brazilian medicinal plants. Journal of Ethnopharmacology, 97: 305-311.

Flora do Brasil. 2019. Cyperus in Flora do Brasil 2020 em construção. Jardim Botânico do Rio de Janeiro. (http://floradobrasil.jbrj.gov. br/reflora/floradobrasil/FB7174). Accessed on 27 Apr 2019.

França, T.C.; Santos, M.G.D.; Figueroa-Villar, J.D. 2008. Malária: aspectos históricos e quimioterapia. Química Nova, 31: 12711278.

Ghafari, S.; Esmaeili, S.; Naghibi, F.; Mosaddegh, M. 2013. Plants used to treat "tabe rebá" (malaria like fever) in Iranian Traditional Medicine. International Journal of Traditional and Herbal Medicine, 1: 168-176.

Girma, S.; Giday, M.; Erko, B.; Mamo, H. 2015. Effect of crude leaf extract of Osyris quadripartita on Plasmodium berghei in Swiss albino mice. BMC Complementary and Alternative Medicine, 15: 184-192.

Goetghebeur, P. 1998. Cyperaceae. In: Kubitzki, K. (Ed.). The Families and Genera of Vascular Plants. v. IV: Flowering Plants, Monocotyledons. Springer Vrlg., Heidelberg, p.141-190.

Gomes, A.P.; Vitorino, R.R.; Costa, A.D.P.; Mendonça, E.G.D.; Oliveira, M.G.D.A.; Siqueira-Batista, R. 2011. Severe Plasmodium falciparum malaria. Revista Brasileira de Terapia Intensiva, 23: 358-369.

Hassanein, H.D.; Nazif, N.M.; Shahat, A.A.; Hammouda, F.M.; Aboutable, E.A.; Saleh, M.A. 2014. Chemical diversity of essential oils from Cyperus articulatus, Cyperus esculentus and Cyperus papyrus. Journal of Essential Oil Bearing Plants, 17: 251-264.

Katsuno, K.; Burrows, J.N.; Duncan, K.; Huijsduijnen, R.H.V.; Kaneko, T.; Kita, K. 2015. Hit and lead criteria in drug discovery for infectious diseases of the developing world. Nature Reviews Drug Discovery, 14: 751-758.

Kaushik, N.K.; Bagavan, A.; Rahuman, A.A.; Mohanakrishnan, D.; Kamaraj, C.; Elango, G.; et al. 2013. Antiplasmodial potential of selected medicinal plants from eastern Ghats of South India. Experimental Parasitology, 134: 26-32.

Lambros, C.; Vanderberg, J.P. 1979. Synchronization of Plasmodium falciparum erythrocytic stages in culture. The Journal of Parasitology, 65: 418-420.

Landier, J.; Parker, D.M.; Thu, A.M.; Carrara, V.I.; Lwin, K.M.; Bonnington, C.A.; Pukrittayakamee, S.; Delmas, G.; Nosten, F.H. 2016. The role of early detection and treatment in malaria elimination. Malaria Journal, 15: 363.

Meneguetti, D.U.O; Cunha, R.M.; Lima, R.A.; Oliveira, F.A.S.; Medeiros, S.; Sol, D.; et al. 2014. Antimalarial ethnopharmacology in the Brazilian Amazon. Revista de Ciências Farmacêuticas Básica e Aplicada, 35: 577-587.

Metuge, J.A.; Nyongbela, K.D.; Mbah, J.A.; Samje, M.; Fotso, G.; Babiaka, S.B.; Cho-Ngwa, F. 2014. Anti-onchocerca activity and phytochemical analysis of an essential oil from Cyperus articulatus L. BMC Complementary and Alternative Medicine, 14: 223-232.
Mongelli, E.; Desmarchelier, C.; Coussio, J.; Ciccia, G. 1995. Antimicrobial activity and interaction with DNA of medicinal plants from the Peruvian Amazon region. Revista Argentina de Microbiologia, 27: 199-203.

Moreira, P.O.L.; de Souza Barbosa, C.; Silva, K.C.; Gonçalves, A.M.M.N.; Silva, L. M.; Viana, G.H.R.; Varotti, F.P. 2015. Síntese e avaliação da atividade citotóxica in vitro de análogos de alcalóides 3-alquilpiridínicos contendo o grupo tiossemicarbazona. Revista Cientifica da Faculdade de Medicina de Campos, 10: 17-21.

Nicoli, C.M.; Homma, A.O.K.; Matos, G. B.; Menezes, A.J.E.A. 2006. Aproveitamento de biodiversidade amazônica: o caso da priprioca. Embrapa Amazônia Oriental, Belém, Pará, 27p.

Nyasse, B.; Ghogomu, R.; Sondengam, T.B.; Martin, M.T.; Bodo, B. 1988. Mandassidione and other sesquiterpenic ketones from Cyperus articulatus. Phytochemistry, 27: 3319-3321.

OECD. 2001. Guideline for Testing of Chemicals: Acute Oral ToxicityAcute Toxic Class Method. Guideline: 423. Organization for Economic Cooperation and Development, Paris. 14p. (https:// ntp.niehs.nih.gov/iccvam/suppdocs/feddocs/oecd/oecd_gl423. pdf). Accessed on 06 Feb 2018.

Oladosu, I.A.; Usman, L.A.; Olawore, N.O.; Atata, R.F. 2011. Antibacterial activity of rhizomes essential oils of two types of Cyperus articulatus growing in Nigeria. Advances in Biological Research, 5: 179-183.

Olawore, N.O; Usman, L.A.; Ogunwande, I.A.; Adeleke, K.A. 2006. Constituents of rhizome essential oils of two types of Cyperus articulatus L. grown in Nigeria. Journal of Essential Oil Research, 18: 604-606.

PAHO. 2018. Organización Panamericana de la Salud / Organización Mundial de la Salud. Actualización Epidemiológica: Aumento de malaria en las Américas. Washington, D.C. (https://www.paho.org/hq/index.php?option=com docman $\&$ view = download \&category_slug=20189582\&alias $=43437-30$-enero $-2018-$ malaria - actualizacion epidemiologica- 437 \&Itemid=270\&lang=pt). Accessed on 09 Nov 2018.

Peters, W. 1985. The problem of drug resistance in malaria. Parasitology, 90: 705-715.

Pinto, R.M.; Sampaio, V.S.; Melo, G.C.; Alecrim, M.G.C.; Mattos, K.; Perdomo, R.T.; et al. 2019. Overview of artemisinin effectiveness during outset years of its implementation in the western Brazilian Amazon. Memórias do Instituto Oswaldo Cruz, 114: e180075.

Pohlit, A.M.; Lima, R.B.S.; Frausin, G.; Silva, L.F.R.; Lopes, S.C.P.; Moraes, C.B. 2013. Amazonian plant natural products: perspectives for discovery of new antimalarial drug leads. Molecules, 18: 9219-9240.

Rakotonirina, V.S.; Bum, E.N.; Rakotonirina, A.;Bopelet, M. 2001. Sedative properties of the decoction of the rhizome of Cyperus articulatus. Fitoterapia, 72: 22-29.

Recuenco, F.C.; Takano, R.; Sugi, T.; Takemae, H.; Murakoshi, F.; Ishiwa, A.; et al. 2017. Assessment of the growth inhibitory effect of gellan sulfate in rodent malaria in vivo. Japanese Journal of Veterinary Research, 65: 207-212. 
Reiners, A.A.O.; Azevedo, R.C.D.S.; Ricci, H.A.; Souza, T.G.D. 2010. User adherence and reactions to malaria treatment: implications for health education. Texto \& Contexto-Enfermagem, 19: 536-544.

Rezende, L.C.D.; Fumagalli, F.; Bortolin, M.S.; Oliveira, M.G.; Paula, M.H.; Andrade-Neto, V.F; et al. 2013. In vivo antimalarial activity of novel 2-hydroxy-3-anilino-1, 4-naphthoquinones obtained by epoxide ring-opening reaction. Bioorganic \& Medicinal Chemistry Letters, 23: 4583-4586.

Rossati, A.; Bargiacchi, O.; Kroumova, V.; Zaramella, M.; Caputo, A; Garavelli, P.L. 2016. Climate, environment and transmission of malaria. Le Infezioni in Medicina, 24: 93-104.

Rukunga, G.M.; Muregi, F.W.; Omar, S.A.; Gathirwa, J.W.; Muthaura, C.N.; Peter, M. G. 2008. Anti-plasmodial activity of the extracts and two sesquiterpenes from Cyperus articulatus. Fitoterapia, 79: 188-190.

Rukunga, G.M.; Gathirwa, J.W.; Omar, S.A.; Muregi, F.W.; Muthaura, C.N.; Kirira, P.G.; et al. 2009. Anti-plasmodial activity of the extracts of some Kenyan medicinal plants. Journal of Ethnopharmacology, 121: 282-285.

Samy, K.; Kadarkari, M. 2011. Antimalarial activity of traditionally used Western Ghats plants from India and their interactions with chloroquine against chloroquine-tolerant Plasmodium berghei. Vector-Borne and Zoonotic Diseases, 11: 259-268.

Shearer, F.M.; Huang, Z.; Weiss, D.J.; Wiebe, A.; Gibson, H.S.; Battle, K.E.; et al. 2016. Estimating geographical variation in the risk of zoonotic Plasmodium knowlesi infection in countries eliminating malaria. PLoS Neglected Tropical Diseases, 10: e0004915.

Souza, G.A.; Silva, N.C.; Souza, J.; Oliveira, K.R.; Fonseca, A.L.; Baratto, L.C.; Oliveira, E.C.P.; Pilla Varotti, F.; Moraes, W.P. 2017. In vitro and in vivo antimalarial potential of oleoresin obtained from Copaifera reticulata Ducke (Fabaceae) in the Brazilian Amazon rainforest. Phytomedicine, 24: 111-118.

Thebtaranonth, C.; Thebtaranonth, Y.; Wanauppathamkul, S.; Yuthavong, Y. 1995. Antimalarial sesquiterpenes from tubers of Cyperus rotundus: structure of 10,12-peroxycalamenene, a sesquiterpene endoperoxide. Phytochemistry, 40: 125-128.
Trager, W.; Jensen, J.B. 1976. Human malaria parasites in continuous culture. Science, 193: 673-675.

Tuju, J.; Kamuyu, G.; Murungi, L.M.; Osier, F.H.A. 2017. Vaccine candidate discovery for the next generation of malaria vaccines. Immunology, 152: 195-206.

Weenen, H.; Nkunya, M.H.H.; Bray, D.H.; Mwasumbi, L.B.; Kinabo, L.S.; Kilimali, V.A.E.B.; Wijnberg, J.B.P.A. 1990. Antimalarial compounds containing an $\alpha, \beta$-unsaturated carbonyl moiety from Tanzanian medicinal plants. Planta Medica, 56: 371-373.

WHO. 2001. Antimalarial Drug Combination Therapy: Report of a WHO Technical Consultation. World Health Organization, Geneva. 36p. (http://apps.who.int/iris/ bitstream/10665/66952/1/WHO_CDS_RBM_2001.35.pdf.). Accessed on 23 Apr 2019.

WHO. 2016. World Malaria Report 2016. World Health Organization, Geneva. 186p. (http://apps.who.int/iris/ bitstream/handle/10665/252038/9789241511711-eng.pdf;jse ssionid=918E281E743E31DAC7A44ADA11AF2D38?sequen ce=1). Accessed on 09 Nov 2018 .

Woodrow, C.J.; White, N.J. 2017. The clinical impact of artemisinin resistance in Southeast Asia and the potential for future spread. FEMS Microbiology Reviews, 41: 34-48.

Zoghbi, M.D.G.B.; Andrade, E.H.A.; Oliveira, J.; Carreira, L.M.M.; Guilhon, G.M. S. 2006. Yield and chemical composition of the essential oil of the stems and rhizomes of Cyperus articulatus L. cultivated in the State of Pará, Brazil. Journal of Essential Oil Research, 18: 10-12.

Zoghbi, M.D.G.; Andrade, E.H.; Carreira, L.M.; Rocha, E.A. 2008. Comparison of the main components of the essential oils of "priprioca": Cyperus articulatus var. articulatus L., C. articulatus var. nodosus L., C. prolixus Kunth and C. rotundus L. Journal of Essential Oil Research, 20: 42-45.

RECEIVED: 09/11/2018

ACCEPTED: 23/07/2019

ASSOCIATE EDITOR: Valdir Veiga Junior 